\section{Flurprimidol Is Effective at Controlling Height of 'Star Gazer' Oriental Lily}

\author{
Brian A. Krug, \\ Brian E. Whipker ${ }^{1}$, and \\ Ingram McCall
}

AdDitional INDEX WORDs. chemical growth regulators, hybrid lily, plant growth regulators, Topflor, Sumagic, uniconazole

SUMMARY. Flurprimidol preplant soaks, foliar sprays, and substrate drenches were compared to commercially recommended concentrations of uniconazole as a preplant bulb soak and a foliar spray for height control of 'Star Gazer' oriental lily (Lilium hybrids). Foliar sprays of uniconazole at $10 \mathrm{mg} \cdot \mathrm{L}^{-1}(\mathrm{ppm})$ did not control plant height and foliar sprays of flurprimidol concentrations $\geq 80 \mathrm{mg} \cdot \mathrm{L}^{-1}$ provided only minimal height control. Substrate drenches of flurprimidol at $0.5 \mathrm{mg} /$ pot a.i. $(28,350 \mathrm{mg}=1$ oz) controlled plant height, resulting in plants $45.3 \mathrm{~cm}$ (17.83 inches) tall, which were $24 \%$ shorter than the untreated control. Uniconazole preplant bulb soaks of 5 and $10 \mathrm{mg} \cdot \mathrm{L}^{-1}$ controlled plant height, resulting in plants $41.8 \mathrm{~cm}$ (16.46 inches) and $37.8 \mathrm{~cm}$ (14.88 inches), respectively. Preplant bulb soaks of flurprimidol (25 to $400 \mathrm{mg} \cdot \mathrm{L}^{-1}$ ) were applied and a concentration of $25 \mathrm{mg} \cdot \mathrm{L}^{-1}$ resulted in plants $47.7 \mathrm{~cm}$ (18.78 inches) tall, which were $23 \%$ shorter than the untreated control. Flurprimidol substrate drenches and preplant bulb soaks at concentrations of $0.5 \mathrm{mg} /$ pot a.i. and $25 \mathrm{mg} \cdot \mathrm{L}^{-1}$, respectively, were effective in controlling height in 'Star Gazer' lily. In Expt. 2, flurprimidol substrate drenches were applied as ei-

Department of Horticultural Science, Box 7609, North Carolina State University, Raleigh, NC 27695-7609.

${ }^{1}$ To whom reprint requests should be addressed; e-mail: bwhipker@ncsu.edu

This research was funded in part by the North Carolina Agriculture Research Service (NCARS), Raleigh. Use of trade names in this publication does not imply endorsement by the NCARS of products named nor criticism of similar ones not mentioned. Thanks to Berger for the root substrates, Scotts for the fertilizer, Dillen Products for the pots, and for grant support, the North Carolina Commercial Flower Growers' Association and SePRO Co. ther a single or two split applications. A one-time flurprimidol substrate drench of $0.5 \mathrm{mg} /$ pot a.i. provided similar control as two split applications of $0.25 \mathrm{mg} /$ pot a.i.

$\mathrm{H}$ ybrid lilies have been grown as cut flowers for many years and have recently increased in popularity as a potted plant due to the high crop value per square foot of greenhouse space and relative ease of growing (Hamrick, 2003). Many of the vigorous lily cultivars grown as cut flowers are also used for pot plant production, and use of plant growth regulators (PGRs) is usually required to obtain plants of acceptable size (Whipker and Hammer, 1993). While the commercially acceptable height for a pot lily would be between 30 and $40 \mathrm{~cm}$ (11.8 to 15.7 inches) from the pot rim to the top of the plant, 'Star Gazer' is a more vigorous cultivar and an untreated plant can grow to 50 to $60 \mathrm{~cm}$ (19.7 to 23.6 inches) tall (DeHertogh, 1996).

Several PGRs are currently recommended to control excessive growth of oriental lilies. Ancymidol (A-Rest; SePRO, Carmel, Ind.) has been recommended as a substrate drench at 0.125 to $1 \mathrm{mg} /$ pot a.i., with lower concentrations often being applied multiple times, as a foliar spray at 0.5 $\mathrm{mg} /$ plant, and as a preplant bulb soak at $4 \mathrm{mg} \cdot \mathrm{L}^{-1}$ for $30 \mathrm{~min}$ (Bailey and Miller, 1989a; Bearce and Singha, 1990; DeHertogh, 1996; Dole and Wilkins, 2005; Hamrick, 2003; Whipker and Hammer, 1993; Wilkins and Grueber, 1983).

Uniconazole (Sumagic; Valent USA, Marysville, Ohio) has been recommended as a substrate drench $(0.05$ to $0.3 \mathrm{mg} /$ pot a.i.), a foliar spray ( 5 to $\left.15 \mathrm{mg} \cdot \mathrm{L}^{-1}\right)$, and also as a preplant bulb soak $\left(0.25\right.$ to $10 \mathrm{mg} \cdot \mathrm{L}^{-1}$ ranging from 1 to $30 \mathrm{~min}$, with lower concentrations soaked for longer durations) (Bailey and Miller, 1989a, 1989b; Bearce and Singha, 1990; DeHertogh, 1996; Dole and Wilkins, 2005; Hamrick, 2003; Jiao et al., 1990; Ranwala et al., 2002; Whipker and Hammer, 1993). Uniconazole has an advantage over ancymidol due to higher activity at lower doses (Bailey and Miller, 1989a). Preplant uniconazole soaks have been reported to be more effective than substrate drenches (Bearce and Singha, 1990). Paclobutrazol (Bonzi; Syngenta, Greensboro, N.C.) can also 
be used to control height for lilies as a preplant bulb soak at 100 to 200 $\mathrm{mg} \cdot \mathrm{L}^{-1}$ for $30 \mathrm{~min}$ (Dole and Wilkins, 2005; Hamrick, 2003).

Flurprimidol (Topflor, SePRO Corp., Carmel, Ind.) has been available in Europe for over 20 years as a 1.5\% formulation and is being introduced into the U.S. market as a $0.38 \%$ formulation (M. Bell, personal communication). At this time commercial dose recommendations for oriental lilies are not available. Therefore, Expt. I was conducted to determine the efficacy of preplant bulb soaks, foliar sprays, and substrate drenches of flurprimidol on 'Star Gazer' oriental lily. Expt. 2 was conducted as a result of initial trials to determine if multiple applications of flurprimidol substrate drenches result in more consistent height control.

\section{Materials and methods Experiment 1}

Case-cooled 'Star Gazer' oriental lily bulbs [12 to $14 \mathrm{~cm} \mathrm{(4.7} \mathrm{to} 5.5$ inches) diameter] were potted, two bulbs per pot, in $15.2-\mathrm{cm}$-diameter (6 inches) round plastic pots with a volume of $1.9 \mathrm{~L}(2 \mathrm{qt})$ on $22 \mathrm{Jan}$. 2003. The root substrate was Berger BM 6 (Berger Peat Moss, St. Modeste, Que.), which contained $75 \%$ to $80 \%$ Canadian sphagnum peat and 20\% to $25 \%$ perlite. Plants were placed in a greenhouse under natural day length after potting with day/night temperature set points of $20.0 / 18.3$ ${ }^{\circ} \mathrm{C}\left(68 / 65^{\circ} \mathrm{F}\right)$. Plants were fertilized weekly with $150 \mathrm{mg} \cdot \mathrm{L}^{-1}$ nitrogen $(\mathrm{N})$ using $15 \mathrm{~N}-0 \mathrm{P}-12.5 \mathrm{~K}$.

Plant growth Regulator TREATMENTS. On 22 Jan. 2003, preplant bulb soaks were applied for 10 min: flurprimidol $(0.38 \%)$ at 25,50 , 100,200 , or $400 \mathrm{mg} \cdot \mathrm{L}^{-1}$; or uniconazole at 5 or $10 \mathrm{mg} \cdot \mathrm{L}^{-1}$. Substrate drenches and foliar sprays were applied on 22 Feb. when shoots were 7.6 to $10.2 \mathrm{~cm}$ (3 to 4 inches) tall. Substrate drenches of flurprimidol were applied with $118.3 \mathrm{~mL}(4 \mathrm{fl} \mathrm{oz})$ solution per pot at $0.25,0.5,1,2$, or $4 \mathrm{mg} /$ pot a.i. Foliar sprays of flurprimidol at 5 , $10,20,30,40,60,80,120$, or 160 $\mathrm{mg} \cdot \mathrm{L}^{-1}$; or uniconazole at $10 \mathrm{mg} \cdot \mathrm{L}^{-1}$ were applied based on the application rate of $203.7 \mathrm{~mL} \cdot \mathrm{m}^{-2}\left(0.5 \mathrm{gal} / 100 \mathrm{ft}^{2}\right)$. An untreated control was also included. The experiment was a completely randomized design with six single-plant replications of the 23 treatments. Emergence dates (for bulbs treated with soaks), anthesis date (one flower per pot fully opened), plant height at anthesis (measured from the soil line to the uppermost tip of the inflorescence), and number of buds on the stem with the first open flower were recorded.

\section{Experiment 2}

Case-cooled 'Star Gazer' oriental lily bulbs $[16$ to $18 \mathrm{~cm}(6.3$ to 7.1 inches) diameter] were potted in Berger BM 6 with one bulb per pot in $15.2-\mathrm{cm}$-diameter round plastic pots with a volume of $1.9 \mathrm{~L}$ on 23 Jan. 2004. Plants were placed in a greenhouse under natural day lengths after potting with day/night temperature set points of $20.0 / 18.3{ }^{\circ} \mathrm{C}$. Plants were fertilized weekly with $150 \mathrm{mg} \cdot \mathrm{L}^{-1} \mathrm{~N}$ using $15 \mathrm{~N}-0 \mathrm{P}-12.5 \mathrm{~K}$.

Plant growth regulator TREATMENTS. Substrate drenches of flurprimidol were applied with 118.3 $\mathrm{mL}$ solution per pot at three concentrations in either a single or two split applications as follows: on 6 Feb. 2004 when shoots were 7.6 to $10.2 \mathrm{~cm}$ tall the single application of flurprimidol was made at $0.25,0.375$, or $0.5 \mathrm{mg} /$ pot a.i. The split applications were also made on 6 Feb. at $0.125,0.1875$, or $0.25 \mathrm{mg} /$ pot a.i. and repeated at the same concentrations to the same pots on $13 \mathrm{Feb}$.; thus, providing a total dose of $0.25,0.375$, or $0.5 \mathrm{mg} /$ pot a.i. An untreated control was also included. The experiment was a completely randomized design with seven single plant replications of the seven treatments. Anthesis date (one flower per plant fully opened), foliage height at anthesis (measured from the soil line to the lowest peduncle), total plant height at anthesis (measured from the soil line to the uppermost part of the inflorescences), and number of buds on the stem were recorded.

Data Analysis. Data were tested for both experiments by analysis of variance (ANOVA) using general linear model (SAS version 8.2; SAS Institute, Cary, N.C.) and means were separated by least significant differences (LSD) at $P \leq 0.05$. Plant heights at the end of forcing were regressed using PROC REG to determine the best-fit, linear or quadratic model. Terms of the model were evaluated for significance based on comparison of $F$ values at $\alpha=0.05$. PROC NLIN in SAS, as modified by Cox (1992), was used to calculate linear-plateau functions (model IV) relating plant height to flurprimidol preplant soaks. The quadratic and the linear-plateau models were compared to determine the best fit based on $r^{2}$ values.

\section{Results and discussion Experiment 1}

Foliar SPRAYs. Concentrations of flurprimidol $\geq 80 \mathrm{mg} \cdot \mathrm{L}^{-1}$ controlled plant height by $6 \%$ to $13 \%$ (Fig. 1A). A uniconazole foliar spray of $10 \mathrm{mg} \cdot \mathrm{L}^{-1}$ did not control height. Foliar sprays of flurprimidol resulted in minimal height control at the highest concentrations trialed. The minimal amount of control may be explained by the limited leaf area present at the time of applying the foliar spray resulting in decreased efficacy. Further study of flurprimidol foliar sprays is needed to determine the efficacy of multiple applications at lower concentrations as recommended for uniconazole by Bailey and Miller (1989b) and ancymidol by Wilkins and Grueber (1983). Multiple applications of foliar sprays may overcome the limitation of having only a small amount of leaf area when the PGRs were applied in this experiment, and may improve the efficacy of flurprimidol.

SubSTRATE DRENCHES. Flurprimidol substrate drenches $\geq 2 \mathrm{mg} /$ pot resulted in excessive control. Acceptable control was provided by $0.5 \mathrm{mg} / \mathrm{pot}$, resulting in plants $11 \%$ shorter than the untreated control at $53.1 \mathrm{~cm}(20.91$ inches) tall (Fig. 1B). The $4 \mathrm{mg} /$ pot concentration, which is 8 times higher than our recommended concentration of $0.5 \mathrm{mg} /$ pot, reduced the bud count by $28 \%$ and delayed anthesis by $4 \mathrm{~d}(P$ $\leq 0.05$ ) compared to untreated controls. However, neither effect would be considered commercially significant (data not shown).

These results suggested that multiple applications of flurprimidol as a substrate drench should be explored at concentrations lower than $0.5 \mathrm{mg} / \mathrm{pot}$ as is recommended with ancymidol (DeHertogh, 1996; Hamrick, 2003; Wilkins and Grueber, 1983), as in Expt. 2. The high efficacy of flurprimidol substrate drenches along with split applications may provide height control with more uniform internode length.

Preplant soaks. Preplant bulb soaks of flurprimidol $>61.5 \mathrm{mg} \cdot \mathrm{L}^{-1}$ produced the shortest plants at 27.3 $\mathrm{cm}$ (10.75 inches) tall (Fig. 1C), which were $56 \%$ shorter than the untreated control. No further increases in height control occurred at higher concen- 

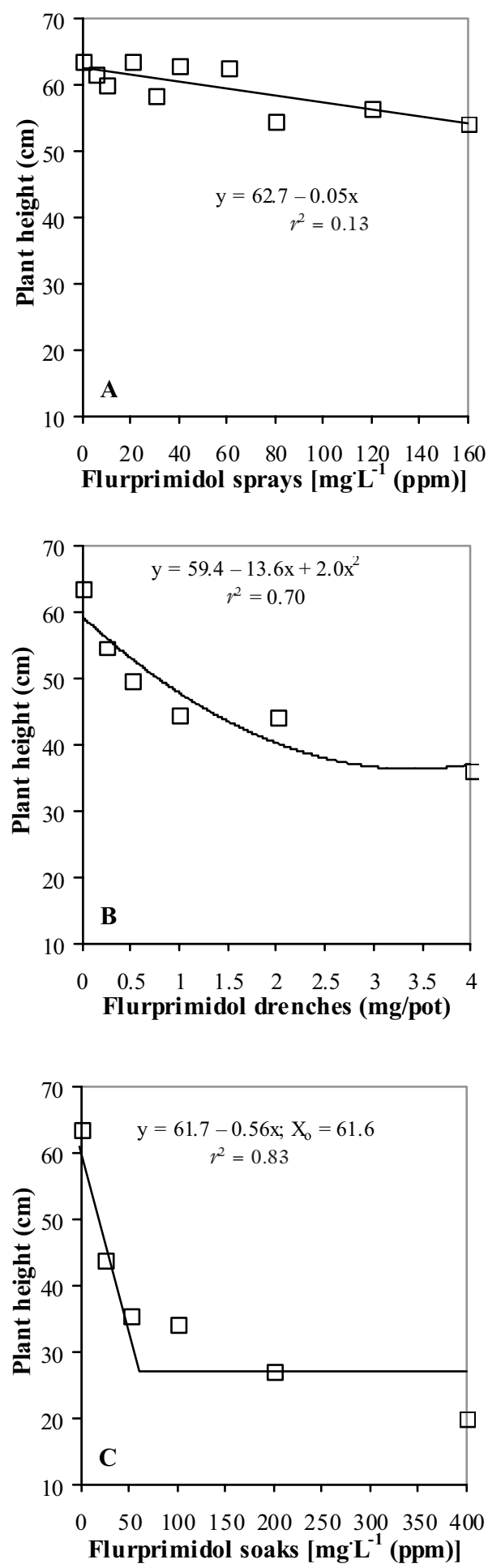

Fig. 1. Effects of flurprimidol foliar sprays (A), substrate drenches (B), and preplant bulb soaks (C) on 'Star Gazer' oriental lily plant height, at anthesis. Data points are means of six replicates $(2.54 \mathrm{~cm}=1$ inch; 28,350 $\mathrm{mg}=\mathrm{loz})$. trations. Concentrations $\geq 61.5$ $\mathrm{mg} \cdot \mathrm{L}^{-1}$ resulted in excessive control. A concentration of $25 \mathrm{mg} \cdot \mathrm{L}^{-1}$ resulted in plants $47.7 \mathrm{~cm}(18.78$ inches) tall (Fig. 1C), which were $23 \%$ shorter than the untreated control and would be considered acceptable by industry standards (R. Milks, personal communication). Delay of shoot emergence $(13 \mathrm{~d})$ and delay of anthesis (9 d) were observed at concentrations $\geq 200 \mathrm{mg} \cdot \mathrm{L}^{-1}$ and lower bud count was observed at $400 \mathrm{mg} \cdot \mathrm{L}^{-1}$. However, these concentrations resulted in excessive height control ( $44 \%$ shorter than the untreated control) and were 8 to 16 times greater than our recommended rate (data not shown). Preplant bulb soaks of uniconazole at 5 or $10 \mathrm{mg} \cdot \mathrm{L}^{-1}$ resulted in plants 41.8 $\mathrm{cm}$ (16.46 inches) and $37.8 \mathrm{~cm}$ (14.88 inches) tall, which were $34 \%$ and $41 \%$ shorter than the untreated control, respectively. To obtain similar control using preplant bulb soaks of flurprimidol, concentrations of 35.5 and 42.7 $\mathrm{mg} \cdot \mathrm{L}^{-1}$ would be required based on regression analysis. Uniconazole at $5 \mathrm{mg} \cdot \mathrm{L}^{-1}$ slightly delayed shoot emergence $(7 \mathrm{~d})$, but neither concentration delayed anthesis nor affected bud count (data not shown). The control obtained by use of uniconazole at $10 \mathrm{mg} \cdot \mathrm{L}^{-1}$ (41\% shorter plants) was greater than the control reported by Ranwala et al. (2002) (22\% shorter plants). Ranwala et al. (2002) soaked the bulbs for only $1 \mathrm{~min}$ whereas in our study bulbs were soaked for $10 \mathrm{~min}$. The duration of the bulb soak along with any year-to-year growth variation could account for differences in control. Uniconazole is more active as a preplant bulb soak at lower concentrations than flurprimidol, but both resulted in commercially acceptable height control.

\section{Experiment 2}

At the same total concentrations, both one-time applications and two split applications of flurprimidol substrate drenches resulted in similar control of foliage height (Fig. 2A). However, total height varied with response to a single application or split application of flurprimidol (Fig. 2C). The
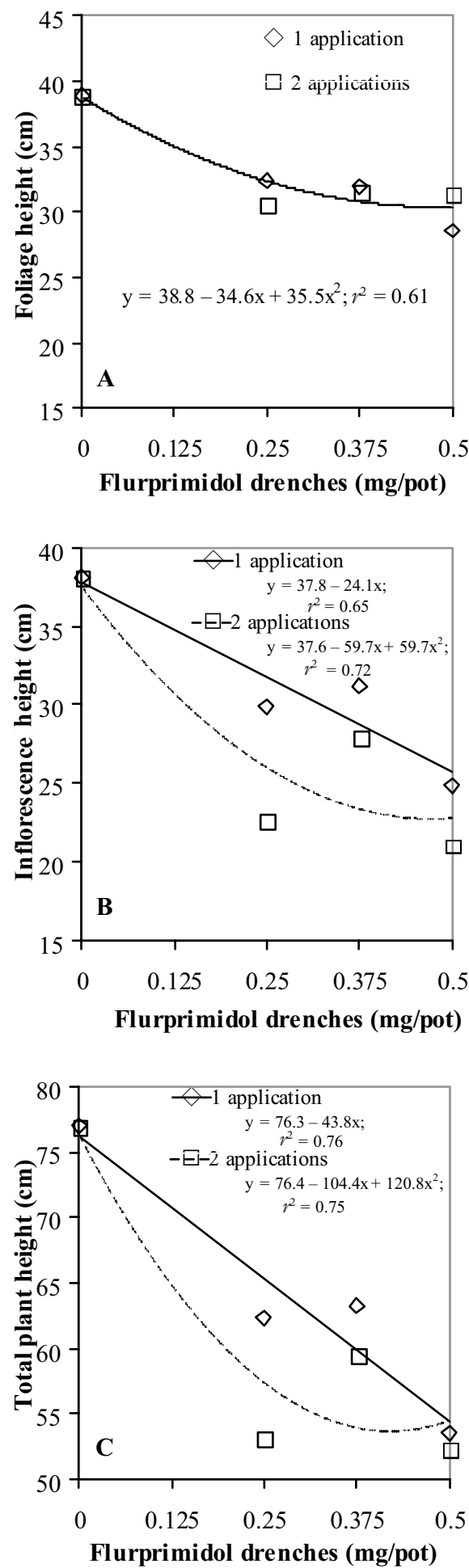

Fig. 2. Effects of flurprimidol substrate drenches applied in one or two applications on foliage height (A), inflorescence height (B), and total plant height (C) on 'Star Gazer' oriental lily plant height, at anthesis. Data points are means of seven replicates $(2.54 \mathrm{~cm}$ $=1 \mathrm{inch} ; 28,350 \mathrm{mg}=1 \mathrm{oz}$ ). 
difference in total plant height was due to the control of inflorescence height (Fig. 2B). Flurprimidol substrate drenches at 0.25 and $0.375 \mathrm{mg} / \mathrm{pot}$ applied in split applications resulted in greater control of inflorescence height and total plant height than a single application (Fig. 2 B and C). However, flurprimidol substrate drenches at 0.5 $\mathrm{mg} /$ pot applied as either single or split applications resulted in similar control of inflorescence height and total plant height. Due to labor costs associated with multiple applications of substrate drenches, we recommend a one-time application of $0.5 \mathrm{mg} / \mathrm{pot}$, which resulted in plants $54.4 \mathrm{~cm}$ (21.42 inches) tall and were $32 \%$ shorter than the untreated control. This would be considered to be acceptable for commercial production (R. Milks, personal communication).

\section{Conclusions}

Flurprimidol is suitable as a single application substrate drench at 0.5 $\mathrm{mg} /$ pot or a preplant bulb soak at $25 \mathrm{mg} \cdot \mathrm{L}^{-1}$ with 'Star Gazer' oriental lily. Further work is required to determine the suitability of foliar sprays. A single substrate drench application of flurprimidol is attractive to growers due labor requirements involved in application and providing height control with uniform internode length. With multiple PGR options available, assessment of the chemical and application costs should be considered by growers to determine the most economically feasible option for height control for 'Star Gazer' oriental lily.

\section{Literature cited}

Bailey, D.A. and W.B. Miller. 1989a. Response of oriental hybrid lilies to ancymidol and uniconazole. HortScience 24:519.

Bailey, D.A. and W.B. Miller. 1989b. Whole-plant response of easter lilies to ancymidol and uniconazole. J. Amer. Soc. Hort. Sci. 114:393-396.

Bearce, B.C. and S. Singha. 1990. Growth and flowering response of asiatic hybrid lilies to uniconazole. HortScience 25:1307.

Cox, F.R. 1992. Range in soil phosphorus critical levels with time. Soil Sci. Soc. Amer. J. 56:1504-1509.

DeHertogh, A. 1996. Lilium (asiatic and oriental hybrids)-Potted plants, p. C109-C121. Holland bulb forcer's guide. Intl. Flower Bulb Ctr., Hillegom, The Netherlands.

Dole, J.M. and H.F. Wilkins. 2005. Floriculture principles and species. Prentice Hall, Upper Saddle River, N.J.

Hamrick, D. 2003. Lilium (asiatic and oriental lilies). Vol. 2. Ball Publ., Batavia, Ill.

Jiao, J., X. Wang, and M.J. Tsujita. 1990. Comparative effects of uniconazole drench and spray on shoot elongation of hybrid lilies. HortScience 25:1244-1246.

Ranwala, A.P., G. Legnani, M. Reitmeier, B.B. Stewart, and W.B. Miller. 2002. Efficacy of plant growth retardants as preplant bulb dips for height control in LA and oriental hybrid lilies. HortTechnology $12: 426-431$.

Whipker, B.E. and P.A. Hammer. 1993. Research report: Oriental lily growth regulator study. Floriculture Indiana Purdue Univ. Hort. Dept. Coop. Ext. Serv. 7:10-16.

Wilkins, H.F. and K.L. Grueber. 1983. Lily-height control: Drenches, sprays, dips. Florists' Rev. 173:50-53. 